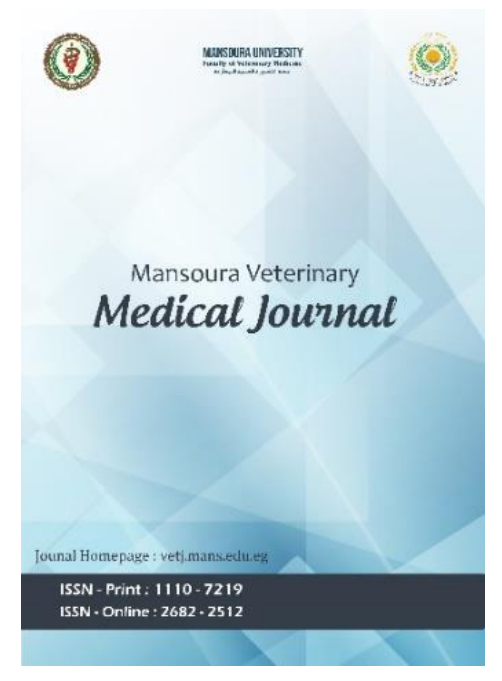

\title{
Evaluation of Hematological and Biochemical Changes in Dromedary Camel during the Different Stages of Lactation
}

\section{Ahmed Adel El-Sayed}

To cite this article: Ahmed El-Sayed. Evaluation of Hematological and Biochemical Changes in Dromedary Camel during the Different Stages of Lactation. Mansoura Veterinary Medical Journal 2020; 21, 3: 121-124.

To link to this article: https://doi.org/10.35943/mvmj.2020.21.320

Published online: 29 September 2020

Submit your article to this journal
CrossMark data 


\section{Evaluation of Hematological and Biochemical Changes in Dromedary Camel during the Different Stages of Lactation}

Ahmed Adel El-Sayed

Department of Animal health and Poultry, Animal and Poultry Production Division, Desert Research Center (DRC), Matariya, Cairo, Egypt

\section{ARTICLE HISTORY}

\section{Received: 15.08 .2020}

Revised: 19.09 .2020

Accepted: 20.09.2020

Address correspondence to Mohamed ElAdl; Tel: +201112242510; fax: 0020220678339; E-mail: decernes@yahoo.com; ORCIDID: org/0000-0001-5049-3964

\section{ABSTRACT}

\begin{abstract}
Objective: To assess the potential hematobiochemical alterations in healthy dromedary camel during the different stages of lactation.

Design: Randomized controlled study.

Animals: Fifteen healthy female dromedary camels, with mean body weight of $499.6 \mathrm{~kg}$ and mean age of 20 years.

Procedures: Camels were categorized into 3 groups' according to their stage of lactation: group 1, early lactation (1-3 months), group 2, mid-lactation (four-6 months) and group3, late lactation ( $\geq 7$ months). Blood samples were collected from every animals for hematological and biochemical evaluation.

Results: Total erythrocyte count (TEC), hemoglobin ( $\mathrm{Hb})$, mean corpuscular volume (MCV), mean corpuscular hemoglobin ( $\mathrm{MCH})$, total leukocytes (TLC), lymphocytes, neutrophils, monocytes, Calcium, glucose, aspartate aminotransferase (AST), alanine transaminase (ALT), gamma glutamyl transferase (GGT) and alkaline phosphatase (ALP) confirmed significant $(p<0.05)$ variation between different stages of lactation. However, non-notable $(p>0.05)$ dissimilarity were located in packed cell volume (PCV), mean corpuscular hemoglobin concentration $(\mathrm{MCHC})$, in organic phosphorus (P), magnesium ( $\mathrm{Mg}$ ), cholesterol, total protein (TP), albumen, globulin, blood urea nitrogen (BUN) and creatinine kinase (CK) in the course of different ranges of lactation,

Conclusion and clinical relevance: The results of this investigation may be useful as reference guide for dromedary camel to evaluate the metabolic health status at different stages of lactation.
\end{abstract}

Keywords: Camel, Hematobiochemical changes, Lactation stages.

\section{INTRODUCTION}

Blood metabolic profile (BMP) that is considered one of the most commonly reported diagnostic procedures that us ed to assess the nutritional status and animal health [1].The most common indicators that are used to accomplish the BMP are biochemical and hematological variables [2]. Many genetic, non-genetic factors and physiological status including the age and reproductive stage have been reported to affect the findings of BMP [2-4]. Lactation period is of utmost significance to the dairy animal and the proper caring with the animal during this critical time will minimize the deleterious metabolic consequences which might affect the performance of the dairy animals $[5,6]$. The BMP is considered a valuable tool that is used for identification, prediction and control of diseases of the lactating animal by providing an idea for successful interpretation of laboratory information [7-9]. It well be accepted that blood and ma mmary gland secretory cells a re the main source of milk and milk components and utilize $80 \%$ of the blood-circulating metabolites for milk synthesis [10].

The data regarding BMPin lactating Egyptian dromedary camel are still lacking. Hence, the present study was delineated to evaluate the influence of different stages of lactation on (BMP) in Egyptian dromedary camel. We hypothesized that the applied BMP could reflect the alterations of physiologic status and provided updated and valuable details about the proper management plans in camel during the lactation periods.

\section{MATERIALS AND METHODS}

\subsection{Animals and management}

Fifteen apparently healthy female dromedary camels with a mean body weight of $499.6 \mathrm{~kg}$ (range: $387-634 \mathrm{~kg}$ ) and mean ages of 20 years (range: 18 -22 years) were used. The camels were considered clinically sound on the basis of physical examination of heart, lungs, rumen and intestine and other vital signs [11]. The animals were also examined for parasites and deworming of the animals was done regularly. All procedures were performed in accordance with the guidel ines of Desert Research Center (Egypt) and approved by its Ethical Committees. Camels were housed in a nopen yard and fed on a maintenance ration composed of a concentrate mixture including $50 \%$ corn, $47 \%$ barley, $2 \%$ minerals, $1 \%$ salt which given at rate of $3 \mathrm{~kg} / \mathrm{head} / \mathrm{day}$, while Egyptian clover hay (Trifolium alexandrinum) and fresh water were offered ad libitium.

\subsection{Study design}

Camels were divided into 3 group's instep of their lactation phase: Early lactation (1-3 months), Mid-lactation (4-6 months) and Late Lactation ( $\geq 7$ months). 


\subsection{Laboratory examination}

\subsubsection{Blood samples}

Two blood samples were collected from each camel via jugular vein puncture into tube with anticoagulant (EDTA or sodium fluoride) and without anticoagulant to yield serum. The tubes containing EDTA were used for hematological examination. On the other side, tubes containing sodium fluoride were used for quantifying concentrations of glucose which were measured spectrophotometrically using a commercial test kit supplied by Spectrum Egypt. The plain tubes were kept at room temperature overnight to be centrifuged at $3000 \mathrm{rpm}$ for 15 minutes. Only clear sera were collected then aliquoted and kept frozen at -20 OC for subsequent biochemical a nalyses using commercial test kits according to the standard protocols of suppliers.

\subsubsection{Hematological profile}

The haematological indices included total leucocytes (WBC) and differentialleukocytes (lymphocytes, neutrophils, monocytes, and eosinophil), red blood cells (RBC), haemoglobin (HGB), hematocrit, mean erythrocyte volume (MCV), mean corpuscular ha emoglobin $(\mathrm{MCH})$, and mean corpuscular haemoglobin concentration $(\mathrm{MCHC})$ were carried out using the automatic blood cell counter (Exigoeos veterina ry Hematology system, Catalogue number; 1420001, Boule Medical AB, Sweden).

\subsubsection{Biochemical serum analysis}

For the (TP), albumen, calcium, $\mathrm{P}$ and $\mathrm{Mg}$ commercial test kits supplied by BioMed Egypt were performed. For AST, ALT ALP, GGT, CK and cholesterol, commercial test kits supplied by Spectrum Egypt were us ed. For BUN, commercial test kits supplied by BioScien Egypt were used.

\subsubsection{Statistical analysis}

Statistical analyses have been finished the usage of a sta ti stical software application (SPSS, ver.20, Inc., Chicago, USA). Descriptive statistics have been performed for all para meters. Repeated mea sure ANOVA beca me us ed to test the effect of va rious periods of lacta tion on (BMP). Outcomes have been taken into consideration statistically significant at $p<0.05$.

\section{RESULTS}

Data summarizing results of the effect of la ctation stage on serial measurements of serum hematological and biochemical profile in dromedary camels a re illustrated in tables 1,2 . Clinically, the investigated camels showed no detectable clinical al terations throughout the study period and remain clinically healthy.

Table 1 summarizes the hematological variables in examined camels during different lactation stages. The TEC and lymphocyte count were significantly $(p=0.001$ and 0.029 ) lowered in mi d lactation while, MCV and MCH levels demonstrated the opposite pattern $(p=0.052$ and 0.002$)$ at the same time point. TLC and monocyte count were significantly $(p=0.019$ and 0.035$)$ higher in late lactation while, neutrophil count had the conflicting pattern at the same time compared with other lactation stages. $\mathrm{Hb}$ levels were significantly $(p=0.037)$ el evated in ea rly lactation while $\mathrm{PCV}$ and $\mathrm{MCHC}$ values were not remarkably $(\mathrm{P}>0.05)$ differed all over the sampling time.

Table 1. Changes of hematological parameters in female dromedary camels at different stages of lactation ( $n=15)$.

\begin{tabular}{|c|c|c|c|c|}
\hline $\begin{array}{l}\text { Groups } \\
\text { Items }\end{array}$ & $\begin{array}{l}\text { Early } \\
\text { lactation } \\
(n=15)\end{array}$ & $\begin{array}{l}\text { Mid } \\
\text { lactation } \\
(n=15)\end{array}$ & $\begin{array}{l}\text { Late } \\
\text { lactation } \\
(n=15)\end{array}$ & P value \\
\hline $\operatorname{TEC}\left(\times 10^{9} / \mathrm{I}\right)$ & $10.3 \pm 0.36$ & $9.3 \pm 0.7^{*}$ & $12.9 \pm 1$ & $0.001^{*}$ \\
\hline $\mathrm{Hb}(\mathrm{g} / \mathrm{dl})$ & $12.9 \pm 0.8^{*}$ & $9.1 \pm 0.5$ & $8.1 \pm 1.2$ & $0.002 *$ \\
\hline PCV (\%) & $33.2 \pm 3.9$ & $33.7 \pm 4.5$ & $37 \pm 4.6$ & 0.589 \\
\hline $\operatorname{MCV}(f \mathrm{fl})$ & $33.3 \pm 3.9$ & $37.1 \pm 4.4^{*}$ & $27.6 \pm 2.5$ & $0.04^{*}$ \\
\hline MCH (pg/cell) & $8.9 \pm 1$ & $11.4 \pm 0.9 *$ & $8.3 \pm 0.6$ & $0.002 *$ \\
\hline MCHC (g/dl) & $32.4 \pm 3.4$ & $32.1 \pm 1.7$ & $28.8 \pm 2.8$ & 0.09 \\
\hline $\operatorname{TLC}\left(\times 10^{9} / \mathrm{I}\right)$ & $5.4 \pm 1.6$ & $9.6 \pm 4.7$ & $11.7 \pm 3.2^{*}$ & $0.019 *$ \\
\hline $\operatorname{Lym}\left(\times 10^{9} / \mathrm{I}\right)$ & $3.1 \pm 1.2$ & $1.5 \pm 0.3^{*}$ & $3.4 \pm 0.4$ & $0.029 *$ \\
\hline Neut $\left(\times 10^{9} / \mathrm{I}\right)$ & $8.1 \pm 1.9$ & $6.9 \pm 2.2$ & $3.2 \pm 1.3^{*}$ & $0.037^{*}$ \\
\hline Mon $\left(\times 10^{9} / I\right)$ & $0.27 \pm 0.15$ & $0.21 \pm 0.01$ & $0.47 \pm 0.09 *$ & $0.035^{*}$ \\
\hline
\end{tabular}

Data are presented as mean $\pm \mathrm{SD}$. *Values with an asterisk within the same raw are statistically significant $(P<0.05)$

$\mathrm{TEC}=$ Total erythrocytes count, $\mathrm{Hb}=$ Hemoglobin, $\mathrm{PCV}=$ Packed cell volume, $\mathrm{MCV}=$ Mean corpuscular volume, $\mathrm{MCH}=$ Mean corpuscular hemoglobin, $\mathrm{MCHC}=$ Mean corpuscular hemoglobin concentration, TLC= Total Leukocytic count, Lym= Lymphocyte, Neut= Neutrophil, Mon= Monocyte.

Table 2. Changes of biochemical parameters in female dromedary camels at different stages of lactation $(n=15)$.

$\begin{array}{lllll}\begin{array}{l}\text { Groups } \\ \text { Items }\end{array} & \begin{array}{l}\text { Early } \\ \text { lactation } \\ \text { (n=15) }\end{array} & \begin{array}{l}\text { Mid } \\ \text { lactation } \\ \text { (n=15) }\end{array} & \begin{array}{l}\text { Late } \\ \text { lactation } \\ \text { (n=15) }\end{array} & \text { P value } \\ \text { Ca (mmol/l) } & 1.5 \pm 0.16^{*} & 2.1 \pm 0.13 & 2.2 \pm 0.03 & 0.006^{*} \\ & & & & \\ \text { P (mmol/l) } & 1.19 \pm 0.26 & 1.17 \pm 0.15 & 0.9 \pm 0.03 & 0.217 \\ \text { Mg (mmol/l) } & 1.2 \pm 0.49 & 1.4 \pm 0.54 & 1.6 \pm 0.18 & 0.413 \\ \text { Gluc (mg/dl) } & 64.3 \pm 3.8^{*} & 99.6 \pm 8.3 & 98.6 \pm 3.5 & 0.031^{*} \\ \text { Chol (mg/dl) } & 42.6 \pm 5 & 38.6 \pm 6.1 & 37 \pm 2.6 & 0.452 \\ \text { TP (g/dl) } & 4.9 \pm 0.6 & 4.7 \pm 0.36 & 4.4 \pm 0.36 & 0.342 \\ \text { Alb (g/dl) } & 3.5 \pm 0.46 & 3.3 \pm 0.34 & 3.1 \pm 0.22 & 0.539 \\ \text { Glob (g/dl) } & 1.5 \pm 0.15 & 1.3 \pm 0.1 & 1.1 \pm 0.13 & 0.351 \\ \text { BUN (mg/dl) } & 4 \pm 0.6 & 4.3 \pm 0.57 & 4.5 \pm 0.24 & 0.591 \\ \text { AST (U/l) } & 158.6 \pm 3.5 & 109 \pm 16.3^{*} & 118.3 \pm 2.8^{*} & 0.005^{*} \\ \text { ALT (U/l) } & 91 \pm 3.6 & 64 \pm 10.5^{*} & 65.3 \pm 4.7^{*} & 0.021^{*} \\ \text { GGT (U/l) } & 23.8 \pm 3.6 & 15.3 \pm 3.7^{*} & 10 \pm 1 * & 0.005^{*} \\ \text { ALP (U/l) } & 83.3 \pm 11 & 65.6 \pm 8.5^{*} & 48.3 \pm 3^{*} & 0.033^{*} \\ \text { CK (U/I) } & 25 \pm 2.6 & 24.6 \pm 2.5 & 26 \pm 2 & 0.499\end{array}$

Data are presented as mean \pm SD. *Values with an asterisk within the same raw are statistically significant $(P<0.05)$

Ca: Calcium; P: Phosphorus; Mg: Magnesium; Gluc: Glucose; Chol: Cholesterol; TP: Total protein; Alb: Albumen; Glob: Globulin; BUN: Blood urea nitrogen; AST: aspartate aminotransferase; ALT: Alanine transaminase; GGT:Gamma glutamyl tranferase; ALP: Alkaline phosphatase; CK: Creatinine kinase

Biochemically, serum values of calcium and glucose showed statistically significant decrease $(P=0.006$ and $P=$ 0.031 , respectively) at early stage of lactation. Serum concentrations of AST, ALT, GGT and ALP were significantly ( $p$ $=0.005,0.021,0.005$ and 0.033 , respectively) lower in mid and late lactation than early lactation. Other biochemical parameters including $\mathrm{P}, \mathrm{Mg}$, cholesterol, TP, albumen, 
globulin, BUN and CK were not significantly $(P>0.05)$ varied all-round the study period (Table 2 ).

\section{DISCUSSION}

The findings of the present study clearly demonstrate significant decrea se of TEC at mid-stage of lactation. These findings were in accordance with the previous studies [12, 13]. Lower TEC in mid la ctation might a lso suggest a negative correlation among better milk production and RBCs attention in lactating animals [2].Unlike to our findings, some a uthors have found a trend of higher values of TEC [14-17]. This variation may be due to differences in breed, physical and environmental conditions. The finding of lymphopenia was in consistent with that shown in previous reports $[12,18]$ in ca mels; but [19] observed a higher lymphocytic count during early lactation.

$\mathrm{Hb}$ significantly increased at early lactation stage which could be attributed to higher demand for oxygen during and after parturition [12-14, 16, 20]. In contrary, other reports recorded a significant decrease $[15,17,21]$.

There were significant high values of $\mathrm{MCV}$ and $\mathrm{MCH}$ at mid-lactation. This finding was in part similar to some reports $[12,13]$ and disagreed with other results $[14,16,20]$. There was a non-significant $(P>0.05)$ va riation of $P C V \%$ a nd $M C H C$ values throughout the study period. In contrast, some reports observed significant changes $[12,16]$. However, the difference within the values of (TLC) and monocyte count can be assigned to the variations in species, nutrients, husbandry, environment and strategies of assay [22]. The finding of neutropenia at late lactation was nearly similar to previous results $[12,18]$.

Hypocalcaemia was evident in the examined camels particularly at the early lactation period. Similar finding was observed in some reports $[20,23]$. In the later study, the authors allocated such finding to excessive secretion of blood calcium through colostrum and milk andits rearrangement in bone [24]. Unlike to our findings, [21] noted that the highest and lowest levels of calcium observed in mid and late lactation, respectively in Holstein dairy cows.

Hypoglycemia was proof in the present work at early stage of lactation which could be attributed to the utilization of l arge amount of blood gl ucose by mammary gland for the synthesis of lactose likewise; the lactose production is as sociated with higher glucose uptake by lactating mammary gland [25]. These results were in consistent with some records $[4,20,21]$. In contrary to the above results, [26] concluded that, the serum glucose values were the same all over the lactation period, whereas, [27] showed higher glucose level at parturition then declined during lactation period in beef cattle. On the other hand, $\mathrm{P}$ and $\mathrm{Mg}$ showed non-significant changes; however, other reports recorded significant changes [28-30].

Serum concentrations of cholesterol were not significantly differed all-round the sampling time. Our results were in harmony with that given by [17], but in opposite to that recorded in crossbred Istrian $x$ East Friesian dairy ewes
[31] who showed a significant increase of cholesterol levels at la te lactation period. The authors attributed such finding to low milk production and decreased requirements for substances needed for the mi lkfat synthesis. On the contrary, TP, albumen, globulin and BUN showed a non-significant variations at all sampling time, suggesting non-deleterious effect on the camels' health.

In our study, The AST, ALT, GGT and ALP concentrations were decrea sed significantly at mid a nd late lactation. Nearly similar finding was given by several authors el sewhere [16, $32,33]$.

The increased level of AST, ALT, GGT and ALP during early lactation can be because of massive physiological and biochemical modifications of liver to overcome the side results of negative strength balance. Later on, the ongoing drop of AST, ALT and GGT concentration with the progress of lactation may due to the destruction of the cellular structure of body, which might also suggest hepatic lipidosis, damage of hepatocytes and release of intracellular enzymes into circulation [2]. However, the greater ALP level during the beginning of lactation can also assign to accelerate the production of ALP by placenta to reinforce the oes teoblastic activity of the fetus. Away from our finding, Cozzi et al. [34] and Ronald et al. [20] found non-outstanding variation in serum AST and ALT concentration all through the lactation period in Holstein dairy cows and Mehshani buffaloes, respectively while, Cozzi et al. [34] noted decreased concentration of GGT in Holstein da iry cows. In the opposite, CK showed a non-significant variations at all sampling time. CK is usually concentrated in muscles, myocardium and brain. In consequence non-significant changes in CK levels may point out good farm management by absence of any stress have the ability to induce muscle damage. These findings were in agreement with that given in camels [16,33], but not agreeable with that reported previously [22].

\section{Conclusion}

The data herein demonstrated a profound haematobiochemical alteration during the different stages of la ctation in dromedarycamels. Such alterations could reflect a physiological variation and could be used as a reference guide for she-camels during the different lactation periods.

\section{Acknowledgments}

The a uthors acknowledge the staff members of Animal Health and Poultry Department, Desert Research Center, Egypt.

\section{Conflict of Interest statement}

The a uthors declare that they have no conflict of inter est.

\section{Ethical approval}

All procedures were performed in accordance with the guidel ines of Desert Research Center (Egypt) and approved by its Ethical Committees. 


\section{REFERENCES}

[1] Ahmad I, Gohar A, Ahmad N, Ahmad M. Haematological profile in cyclic, non-cyclic and Endometritic Cross-Bred cattle. Int J Agric Biol 2003; 5 332-334.

[2] Antunovic Z, Novoselec J, Sauerwein H, Speranda M, Vegara M, Pavic V. Blood metabolic profile and some of hormones concentration in ewes during different physiological status. Bulg J Agric Sci 2011; 17: 687-695.

[3] Antunovic ZD, Sencic M, Speranda M, Liker B. Influence of the season and the reproductive status of ewes on blood parameters. Small Rum Res 2002; 45: 39-44. https://doi.org/10.1016/S0921-4488(02)00109-8

[4] Roubies N, Panousis N, Fyitianou A, Katsoulos PD, Giadinis N, Karatzias H (2006). Effects of age and reproductive stage on certain serum biochemical parameters of Chios sheep under Greek rearing condition. J Vet Med A Physiol Pathol Clin Med. 2006; 53: 1-6. https://doi.org/10.1111/j.1439-0442.2006.00832.x

[5] Krajnicakova ME, Bekeova E, Kovac G, Kostecky M, Valocky I, Maracek I, Sutiakova I, Lenhardt L. Selected clinical-biochemical parameters in the puerperal period of goats. Bull Vet Inst Pulawy 2003; 47: 177-182.

[6] Iriadam M. Variation in certain haematological and biochemical parameters during the peri-partum period in Kilis does. Small Rum Res 2007; 73: 54-57. https://doi.org/10.1016/j.smallrumres.2006.11.001

[7] Carcangiu V, Vacca GM, Mura MC, Dettori ML, Pazzola M, Fioro M, Bini PP. Blood parameters during lactation and dry period in sarda sheep breed. In: Proceed Atti XV Congresso Fe.Me.S.P.Run 2007; Kusadasi, Turkey, 15-20.

[8] Antunović Z, Šperanda M, Steiner Z, Vegara M, Novoselec J, Djidara M. Blood metabolic profile of Tsigai sheep in organic production. Krmiva 2009; 51: 207-212.

[9] Roland L, Drillich M, Iwersen M. Hematology as a diagnostic tool in bovine medicine. J. Vet. Diagn Invest 2014; 26: 592-598. https://doi.org/10.1177/1040638714546490

[10] Piccione G, Caola G, Giannetto C, Grasso F, Runzo SC, Zumbo A, Pennisi P. Selected biochemical serum parameters in ewes during pregnancy, post-parturition, lactation and dry period. Anim Sci Pap Rep 2009; 27: 321-330.

[11] Radostits OM, Mayhew IG, Houston DM. Veterinary Clinical Examination and Diagnosis. W.B. Saunders, London. 2000.

[12] Farooq U, Samad H, Khurshi A, Sajjad S. Normal reference hematological values of one-humped camels (camelus dromedarius) kept in cholistan desert. J Anim Plant Sci 2011; 21: 157-160.

[13] Joshi AB, Abdul Lateef, Nilufar H, Patel AG, Pankaj A. Erythrocytic Indices of Kutchi Camel during Different Stages of Lactation. Advan Anim Vet Sci 2017; 5: 456-459. https://doi.org/10.17582/journal.aavs/2017/5.11.456.459

[14] Al-Busadah KA, Osman TEA. Hematological Parameters of Adult Dry, Lactating and Camel Calves in Saudi Arabia. Pak J Biol Sci 2000; 3: 17491751. https://doi.org/10.3923/pjbs.2000.1749.1751

[15] Hagawane SD, Shinde SB, Rajguru DN. Haematological and Blood Biochemical Profile in Lactating Buffaloes in and around Parbhani city. Vet World 2012; 2: 467-469.

[16] Tharwat M, Ali A, Al-Sobayil F, Selim L, Abbas H. Haematobiochemical profile in female camels (camelus dromedarius) during the periparturient period. J Camel Pract Res 2015; 22: 101-106. https://doi.org/10.5958/2277-8934.2015.00016.8

[17] El-Tarabany S, El-Tarabany A, Roushdy M. Impact of lactation stage on milk composition and blood biochemical and hematological parameters of dairy Baladi goats. Saudi. J Biol Sci 2016; 25: 1632-1638. https://doi.org/10.1016/j.sjbs.2016.08.003

[18] Axay J, Nilufar H, Abdul Lateef, Ajay P, Pankaj P, Nikita B. Study on Blood Metabolites and Leukocyte Indices of Kutchi Camels During Different Stages of Lactation. J Anim Health Product 2017; 5: 92-96. https://doi.org/10.17582/journal.jahp/2017/5.3.92.96

[19] Hussein M, Salah M, Mogawer H, Garelnabi A. Effect of Lactation on the Haemogram and Certain Blood Constituents of the Dromedary Camel. J Appl Anim Res 1992; 1: 43-50. https://doi.org/10.1080/09712119.1992.9705907

[20] Das H, Lateef A, Panchasara H, Ali MA. Haemato-biochemical alterations during different stages of lactation in Mehshani buffaloes. Buffalo Bull 2016; 35, 307-315.

[21] Nozad S, Ramin A, Moghaddam GH, Asri-Rezaei S, Kalantry N. Monthly evaluation of blood hematological, biochemical, mineral, and enzyme parameters during the lactation period in Holstein dairy cows. Comp
Clinic Path 2014; 23: 275-281. https://doi.org/10.1007/s00580-0121607-2

[22] Osman TEA, Al-Busadah KA. Normal Concentration of Twenty Serum Biochemical Parameters of She-Camels, Cows and Ewes in Saudi Arabia. Pak J Biol Sci 2003; 6: 1253-1256. https://doi.org/10.3923/pjbs.2003.1253.1256

[23] Nale RA. Metabolic profiling in buffaloes before and after parturition. M.V. Sc. thesis submitted to MAFSU, Nagpur, India. 2003; 29 - 34.

[24] Liesegang A, Risteli J, Wanner M. Bone metabolism of milk goats and sheep during second pregnancy and lactation in comparison to first lactation. J Anim Physiol Anim Nutr 2004; 91: 217-225. https://doi.org/10.1111/j.1439-0396.2007.00695.x

[25] Mirzaei-Aghsaghali A, Fathi H. Lactose in ruminants feeding: a review. Annals of Biological Research 2012; 3: p. 645-650.

[26] Peterson RG, Waldern DE. Repeatabilities of serum constituents in Holstein-Friesians affected by feeding, age, lactation and pregnancy. J Dairy Sci 1981; 64, 822-831. https://doi.org/10.3168/jds.S00220302(81)82653-7

[27] Doornenbal H, Tong AKW, Murray NL. Reference values of blood parameters in beef cattle of different ages and stages of lactation. Can J Vet Res 1988; 52: 99-105.

[28] Dubreuil P, Arsenault J, Belanger D. Biochemical reference ranges for groups of ewes of different age. Vet Rec 2005; 156: 636-638. https://doi.org/10.1136/vr.156.20.636

[29] Brito MA, Gonzalez FD, Ribeiro LA, Campos R, Lacerda L, Barbosa PR, Bergmann G. Blood and milk composition in dairy ewes from southern Brazil: variations during pregnancy and lactation. Ciência Rural 2006; 36: 942-948. https://doi.org/10.1590/S0103-84782006000300033

[30] Antunović Z, Šperanda M, Novoselec J, Đidara M, Mioč B, Klir Z, Samac D. Blood metabolic profile and acid-base balance of dairy goats and their kids during lactation. Veterinarski Arhiv 2017; 87: 43-55.

[31] Masiek T, Mikulec Z, Valpotic' H, Pahovic' S. Blood biochemical parameters of crossbred Istrian x East Friesian dairy ewes: relation to milking period. Ital J Anim Sci 2007; 6: 281-288. https://doi.org/10.4081/ijas.2007.281

[32] Krsmanovic $M$, Dokovic R, Cincovic $M$, Andric D, Bojkovski J. Determination of the active of specific enzymes of blood in the peripartum period and during the full lactation. Biotech Anim Husbandry 2016; 32: 9-14. https://doi.org/10.2298/BAH1601009K

[33] Patelajay G, Joshiaxay B, Haque N, Lateef A, Patel PA. Physiological status of some serum enzymes in Kutchi camel (Camelus dromedaries) during different stages of lactation. Int J Agric Sci 2017; 9: 4184-4187.

[34] Cozzi G, Ravarotto , Fottardo, A, Stefani AL, Contiero B, Moro L, Brscic $M$, Dalvit P. Short communication: Reference values for blood parameters in Holstein dairy cows: Effects of parity, stage of lactation, and season of production. J Dairy Sci 2011; 94: 3895-3901. https://doi.org/10.3168/jds. 2010-3687 